\title{
A Comparative Study of Aggression Level among Contact and Non Contact Sportsmans
}

\author{
Sukashant $^{1}$, S. Patil ${ }^{2}$ \\ Research Scholar, LNCPE-Kerala University
}

\section{Introduction}

Physical education is the most important factor of common education. It is the education through physical activities it means in physical education how much importance goes to physical factor; the same importance goes to psychological factors also. The aim of the education is overall development of human. The aim of the physical education is not out of common education it helps to overall development of child through physical activities.

In older days more people were spent their time by involving in physical activities, also that people are involved in sports only for happiness not for competition or something else.[as the leisure time increased participation in sports activities were also increased. Then physical activities shaped as competition purpose] or but gradually human got his increased leisure time and also increase in no of participants so it turn as a competitive from that day sports has become professional. Now a day ${ }^{\text {ee }}$ in sports the competition is very much high so the person only by having physical activities, motor abilities and other type of physical abilities are not help to reach his goal, without having psychological factors. The training of psychological factors is very much important for the success of sports.

Sport has become one of the most widely practiced human activities Whether as professionals or amateurs, regularly or occasionally, millions of people now engage in the various forms of physical and sporting activity available in the European Union. In addition to its health benefits, sport plays an important economic and social role. It contributes to social integration and inclusion, plays a part in the process of non-formal education, promotes intercultural exchanges and creates. "The life is like sport. The lord is the greatest sportsman .He plays without thinking of winning or loosing". Physical Education is an integral part of total Education. It is an education through physical Fitness, Social Fitness, moral fitness and emotional fitness for an individual to develop not only a good physique but also help in develop desirable social qualities. The word „Sports oc occasionally denotes either to a pleasant part time or somewhat hazardous recreation.

Today sports are considered as international discipline as it develops international understanding and universal brotherhood. Sports develop national character and also it provides to fullest self expression to man and it is one of the fundamental needs. Human being is considered as an intellectual animal that wants to participate in physical activities to attain personal achieve growth and development and to maintain good health. It is natural is both quality and a child to participate in activities like running, jumping, throwing etc.,

Sport is a dynamic, creative, continuous process which gives meaning to reflect and the values believe and ethics of participation. Sports is a chief component in promoting friendship, peace and understanding between people society and country because the trouble free delight come only from sport.

\section{Contact Sports}

Is any sport for which significant physical impact force on players, either deliberate or incidental, is allowed for within the rules of the game. Contact actions includes tackling, blocking and a whole range of other moves that can differ substantially in their rules and degree of application.

Ex:-lacrosse, rugby, American football, water-polo, wrestling, sumo, team-handball, and ice-hockey.....

\section{Non-Contact Sports}

Non contact sports are sports where participants compete alternately in lanes or are physically separated such as to make nearly impossible for them to make contact during the course of a game without committing an out of bounds offence or more likely disqualification.

Ex:- include precision sports such as badminton, golf, curling, body building, tennis, cricket, volleyball, swimming, sprinting and gymnastics etc..

\section{Psychology}

Psychology is the study of human behavior and human relationship. Sports psychology means applying psychological theories and concepts to aspects or sports such as coaching and teaching. Sports psychology is concerned with analyzing human behavior in various types of sport settings. It is individuals ${ }^{\text {ee }}$ behavior acting individually and acting in a group. This sport psychologist uses psychological in assessment techniques and intervention strategies are on effort to help individuals to achieve their optimal performance.

According to M.L.Kamlesh sports psychology is the application or psychological principles to sport and psychological activity at all levels of skill development.

\section{Aggression in Sports}

Used by the athlete to channel their will to win at all odds and determination to sacrifice their own or their opponents, bodies in the Cause of victory. Psychological factor is very 


\section{International Journal of Science and Research (IJSR) \\ ISSN (Online): 2319-7064 \\ Index Copernicus Value (2013): 6.14 | Impact Factor (2014): 5.611}

important thing in performing athlete, so the psychological training is also needed. Psychological parameters include motivation, aspiration, level of anxiety, arousal, aggression and team cohesion etc.

Both the factors of physical and psychological important for the success in the field of sports for that shake sports training will help to develop the physical ability as well as psychological or mental abilities. In the mind of sportsman some factors like fear, worry, social inequality, attitudinal factors are depress his confidence level of sportsman. Human mind is not constant is various time to time so that to avoid this aggression balancing of mind is important.

By having depression the level of aggression is decrease and it is harms his confidence level so he fails to participate in sports. Sometimes he may fail in sports by decreasing his confidence level and the dangerous aggression affects himself as well as others. This level of aggression also depends on the age, environment factors and other sports activities such as individual games, group games etc.. this competitive aggression directly defends upon a person or thing, individual or group.

\section{Types of aggression}

The psychologist MOYAAR has indicated this aggression into 7-different types. Which are link to act the living organisms?

1. Predator aggression.

2. Male-male aggression.

3. Fear induced aggression

4. Anger aggression

5. Territorial aggression

6. Maternal aggression.

7 .Instrumental aggression.

As the same way the aggression has been divided into two types linking to only human beings.

1. Affective aggression

2. Instrumental aggression.

Purpose of the study:- The main purpose of this study is to analyze the level of aggression between contact (basketball and handball) and Non-contact (Cricket and table-tennis) game sportsman's.

Statement of the problem:- "Whether contact game sport persons are having more aggression than non contact sport person".

\section{Hypothesis}

"The level of aggression in contact game players is significantly higher than non-contact game players

\section{Limitations}

1) Non considerable of doping of a sportsman.

2) Can ${ }^{e e} t$ control the environment/surrounding of the sportsman.

3) Non consideration of daily routine activities, training, and food habits of the sportsman.

4) Can ${ }^{e e}$ control of the psychological condition of sportsman.
5) Family background of the subject is not be considered.

6) The response of the subject to the questionnaire might not be honest in all cases and this was recognized as a limitation.

\section{a) Delimitation}

- In this study we selected the sportsman's from table-tennis and cricket as non contact games and from basketball and handball as contact games.

- This study contains the age of a sportsman between 10-16 years.

- The study restricted the sportsman's from contact and non contact tournament who played above district level.

- The study considered both male and female sportsmen.

- This study considered sportsman who belongs to Karnataka state only.

\section{b) Significance of the study}

- It's possible to know aggression of a sportsman. And possible to know which types of aggressiveness he is having.

- It is very helpful to coaches to prepare the reports and training plans.

- It"s possible to understand the psychological and emotional balance of sportsman"s.

- It ${ }^{\text {ee }}$ s possible to compare the level of aggression of sportsman "e from others.

- This study helps the sportsman's to achieve the great achievement.

\section{Methodology}

As discussed earlier the main purpose of the study was investigating the varying levels of aggression between contact and non contact sportsmans. For this purposes the standardized "aggression" Questionnaire was administered. The selection of the subject and procedure followed by the collection of data and analysis used in this study are described in the following sections.

\section{Subjects}

For the study 30 sportsman's from basketball and handball (Non contact event, 15+15) and 30 sportsmen from cricket and table tennis (Contact games, 15+15) who are participated above the district level tournaments were chosen as the subject. The subject for the studies age limit was restricted in the range of 10-16 years.

Table 1: Number of subjects selected for the study from contact and non contact sports.

\begin{tabular}{|c|c|c|c|}
\hline Type of the game & $\begin{array}{c}\text { Name of the game } \\
\text { \&players }\end{array}$ & $\begin{array}{c}\text { Name of the game } \\
\text { \&players }\end{array}$ & Total \\
\hline Contact & Basketball[15] & Handball[15] & 30 \\
\hline Non-contact & Cricket[15] & Table-tennis[15] & 30 \\
\hline
\end{tabular}

The concurrent validity of the Aggression was examined by investigation the comparative between the Aggression levels in game to game. Result strongly supports the concurrent validity of the Aggression.

To measure competition related Aggression of the sportsman ${ }^{\text {ee }}$ to Aggression Questionnaire test (That is 


\section{International Journal of Science and Research (IJSR) \\ ISSN (Online): 2319-7064 \\ Index Copernicus Value (2013): 6.14 | Impact Factor (2014): 5.611}

developed by anandakumar and shukla in 1988) was introduced. Then each sportsman composite score was found .Then that scores was analyzed according to Aggression scale. All 60 sportsmen were first of all provided to following Aggression questionnaire and they were asked to give their opinion strictly independent manner. The contains 25 items.

Aggression questionnaire the some items that are not scored are included in the inventory to reduce the likelihood of an internal response set bias. The standard instruction of the aggression ask respondents to indicate how they "usually feel when competing in sports ${ }^{\text {eeee }}$

Aggression was given to all investigation; the computed questionnaire was scored as follows.

For items 1,4,5,6,9,12,14,16,18,21,22,24, and 25 answer "yes" he scored two point. In the answer "no" get zero point.

For items 2,3,7,8,10,11,13,15,17,19,20,and 23 answer "no" he scored two point. In the answer "yes" get zero point.

\section{Statistical Techniques}

The data that was collected from the subjects was treated statistically. To test the hypotheses data was subjected to independent sample t- test which will locate significant difference between pair of means.

\section{Analysis of Data and Results}

Responses of the contact and non contact sportsman ${ }^{\text {ee }}$ s to the aggression scale, constituted raw data for the present study.
Data collected using the personal data Performa. In pursuance of the objectives of the study, as well as, to test the research hypotheses set up, the data were, subjected to organization, tabulation and statistical analysis. This chapter describes in detail the procedure followed in the analysis of data.

However valid, reliable and adequate the data may be, it does not serve any useful purpose unless it is carefully processed, systematically classified and tabulated, scientifically analyzed, intelligently interpreted and rationally concluded.

After the data had been collected, it was processed and tabulated using Microsoft Excel - 2007 Software. The data collected on level of aggression from contact and non contact sportsman "s the aim of the study is to "A Comperative Study Of Aggression Level Among Contact And Non Contact Sportsmans". Then the data were analyzed with reference to the objectives and hypotheses by using " $t$ " test followed by comparisons were estimated by using levenees test for quality of variances procedures with respect to level aggression. The statistical significance was set at $5 \%$ level of significance $(\mathrm{p}<0.05)$ and the results obtained thereby have been interpreted.

\section{Hypothesis:}

"The level of aggression in contact game players is significantly higher than non- contact game players"

Table 2: Independent sample t-test for contact and non contact gamees sportsmen s aggression score with Mean and Sd

\begin{tabular}{|c|c|c|c|c|c|c|}
\hline $\begin{array}{c}\text { Total Aggression } \\
\text { Score }\end{array}$ & Type of the Game & $N$ & Mean & Std. Deviation & Std.Error Mean & 't' Value Df (58) \\
\cline { 2 - 6 } & "Contact Game" & 30 & 19.5333 & 7.3697 & 1.34484 & \multirow{2}{*}{ 2.85* } \\
\cline { 2 - 6 } & "Non Contact Game" & 30 & 15.3333 & 3.29402 & 0.60140 & \\
\hline
\end{tabular}

From the above table it can be observed that, contact game sportsmen are having higher mean and sd aggression score than the non contact sportsmen. To test whether these means are significantly different data was subjected to independent sample t-test.

From the above independent sample t-test table we can conclude that there is significant difference between in aggression mean scores of contact and non contact sport person at 0.05 level. So from this we can conclude that hypothesis which was proposed by researcher is accepted.

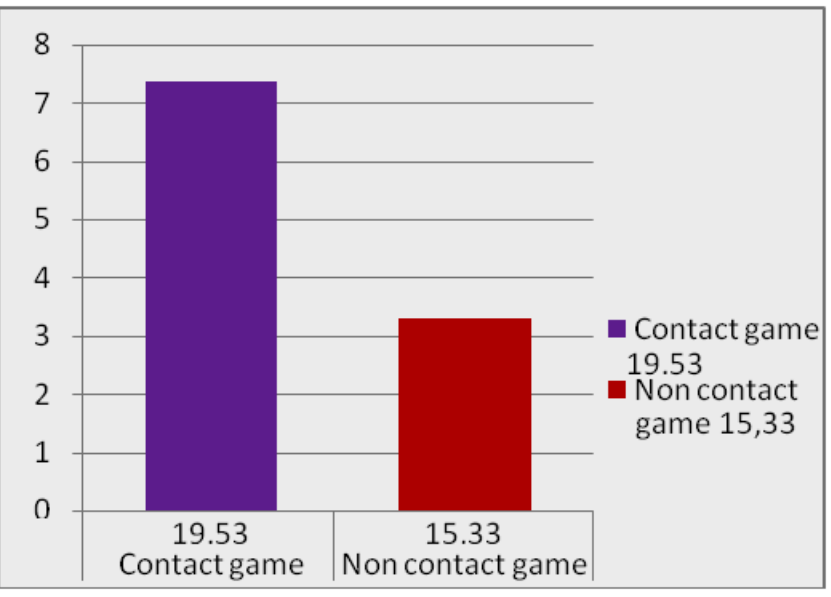

Figure: Comparison of "Contact and Non-contact sportsman "s" with respect to their aggression score.

\section{Results}

From the statistical analyses it is concluded that the sportsmen who are participating in contact sport are having higher aggression than non contact sportsmen. 


\section{Discussion}

As anticipated players who are participating in contact game are having significantly higher aggression score than non contact sportsmen. So it can be predicted that as the body contact of players increases the aggressive behavior also increases. In contact sport lot of contact will happen between the opponents. Some times to take advantage it may express in the form of hostile aggression. Some time losing team will expresses it in the form of frustration. In contact game you have to be aggressive than your opponents to take key positions in the play. In game like basketball players use their aggression to collect the rebound, to attack the rim while scoring and to drive in wherever necessary to score the basket. In non contact game, aggression will be imposed on object with they play. Games like Cricket, badminton and table tennis no contact between the players so you can express you aggression only on the objects with you play on ball, shuttle etc. So there will be very minimum contact in the game. So aggression in contact game is higher than the non contact game. The contact between persons may increase aggression according to Brown (1982) and Martin et al (1972). They concluded that as the body contact increases in 120 games there is also increase in aggressive behavior. Cox (2003) also studied that contact game players have more aggressiveness than non contact game players.

\section{Conclusion}

From the study it may be concluded that contact game sportsmen will have significantly higher aggression than the non contact game sportsmen. According to literature contact in the game may increase the aggression level between players and influences on performance while in non contact game only aggression is limited to objects with they play.

\section{Recommendation}

1) In this study only total aggression is studied. Different aspects of aggression like verbal aggression, physical aggression and hostile aggression will be studied in further studies.

2) This study is only limited to school students. Further it has to be done with college, under graduate and post graduate students.

3) Same study will be done with more number of samples.

\section{References}

[1] Buss, A.H. (1961). The psychology of aggression. New York: Wiley.\& Buss, A.H., Perry, M. (1992). The Aggression Questionnaire. Journal of Personality and Social Psychology, 63, 452-459.

[2] Kelmer; D.S.(1988).Level of athletic, instrumental, and reactive aggression between contact and non-contact, male and female high school athletics under pre and post testing conditions. Unpublished master"s thesis, Southern connecticent state university.

[3] Tesser, L.M. \& Campbell, R.N (1983). Self-definition and self-evaluation maintenance. In J.Suls et A.Greenwald (Eds). Psychological perspectives on the Self, 2 (Hillsdale, N.J.: Erlbaum) 1-31.
[4] Berkowitz, L., (1989). Frustration-aggression hypothesis : Examination and reformulation. Psychological bulletin 106, pp. 59-73.

[5] Buss, A.H and Perry, M(1992). The aggression questionnaire. Journal of personality and social psychology, 63(3), 452-459.

[6] Coleman, D. \& Iso-Ahola, S.E. (1993). Leisure and health: The role of social support and selfdetermination.Journal of Leisure Research, 25, 111-128.

[7] Harter, S. (1998). Comprendre l'estime de soi de l'enfant et de l'adolescent. Considérations historiques, théoriques et méthodologiques. In M.Bolognini et Y.Prêteur (Eds.), Estime de soi: Perspectives développementales. Delachaux et Niestlé, (Paris) 57-81.

[8] qÁ. £ÁqÀVÃgÀ DEÀAzÀ, (2001), zÉÊ»PÀ 2PÀëtzÀ è aÀiËßàa ÀiÁ¥À̀ $¥ \mathrm{ÀæPÁ} \pm$ À£À. 